\title{
ECONOMIC VIABILITY OF BEET CROPS USING Calotropis procera BIOMASS AS SOIL FERTILIZER IN TWO GROWING SEASONS ${ }^{1}$
}

\author{
FALKNER MICHAEL DE SOUSA SANTANA ${ }^{2}$, ÊNIO GOMES FLÔR SOUZA ${ }^{3 *}$, MANOEL GALDINO DOS \\ SANTOS $^{4}$, ANTONIA FRANCILENE ALVES DA SILVA ${ }^{5}$, AURÉLIO PAES BARROS JÚNIOR ${ }^{4}$, \\ HAMURÁBI ANIZIO LINS ${ }^{4}$
}

\begin{abstract}
The use of green manure from spontaneous species has gained prominence for vegetable crops focused on environmental sustainability and is an alternative method for the Semiarid region in the Northeast of Brazil. Two experiments were conducted in two growing seasons (autumn and spring-summer), in Serra Talhada, PE, Brazil, to evaluate the effects of different amounts of biomass of Calotropis procera (roostertree) and incorporation times on the agro-economic performance of beet crops. A randomized block experimental design was used, with three replications, in a $4 \times 4$ factorial arrangement; the first factor consisted of amounts of C. procera biomass $\left(5.4,8.8,12.2\right.$, and $15.6 \mathrm{Mg} \mathrm{ha}^{-1}$ on a dry basis) and the second factor consisted of times of incorporation into the soil $(0,10,20$, and 30 days before planting beet). Commercial root yield, production costs, and the following economic indicators were determined: gross income, net income, return rate, and profitability index. The use of $15.6 \mathrm{Mg} \mathrm{ha}^{-1}$ of $C$. procera biomass resulted in the highest gross and net incomes and the use of 5.4 and $12.2 \mathrm{Mg} \mathrm{ha}^{-1}$ resulted in the best return rates and profitability indexes in autumn and spring-summer seasons, respectively; the planting time was considered as ideal for the biomass incorporation. The spring-summer growing season resulted in a higher economic return than the autumn growing season. The use of $C$. procera as a green manure for beet production is economically viable, regardless of the factors evaluated.
\end{abstract}

Keywords: Beta vulgaris L. Cost. Profitability. Roostertree. Sustainable agriculture.

\section{VIABILIDADE ECONÔMICA DA BETERRABA ADUBADA COM Calotropis procera EM DUAS ÉPOCAS DE CULTIVO}

\begin{abstract}
RESUMO - A utilização da adubação verde com o uso de espécies espontâneas tem ganhando destaque no cultivo de hortaliças, visando a sustentabilidade do ambiente e sendo um método alternativo para o Semiárido nordestino. Dois experimentos foram conduzidos em duas épocas de cultivo (outono e primavera-verão), em Serra Talhada, PE, Brasil, a fim de se avaliar os efeitos de quantidades de biomassa e tempos de incorporação de Calotropis procera (Flor-de-seda) no desempenho agroeconômico da beterraba. O delineamento experimental utilizado foi em blocos casualizados, com três repetições. Os tratamentos foram arranjados em esquema fatorial $4 \times 4$, sendo o primeiro fator correspondente às quantidades de $C$. procera $(5,4 ; 8,8 ; 12,2 \mathrm{e}$ $15,6 \mathrm{Mg} \mathrm{ha}^{-1}$ em base seca) e o segundo, aos tempos de incorporação ao solo $(0,10,20$ e 30 dias antes da semeadura da beterraba). Além da produtividade comercial de raízes e dos custos de produção, foram determinados: renda bruta, renda líquida, taxa de retorno e índice de lucratividade. A quantidade de $15,6 \mathrm{Mg}$ ha ${ }^{-1}$ de $C$. procera promoveu as maiores rendas bruta e líquida, enquanto que as quantidades de 5,4 e $12,2 \mathrm{Mg} \mathrm{ha}^{-1}$ obtiveram as melhores taxas de retorno e índices de lucratividade no outono e primavera-verão, respectivamente, sendo considerada ideal a adubação realizada no momento do plantio. $\mathrm{O}$ cultivo de primaveraverão possibilitou retorno econômico superior à semeadura de outono. Independente dos fatores, o uso da $C$. procera como adubo verde na produção de beterraba foi viável agroeconomicamente.
\end{abstract}

Palavras-chave: Beta vulgaris L. Custo. Rentabilidade. Flor-de-seda. Agricultura sustentável.

\footnotetext{
*Corresponding author

${ }^{1}$ Received for publication in $01 / 11 / 2021$; accepted in 05/26/2021.

${ }^{2}$ Agronomist Engineer, Agrofertilis Consultoria e Projetos, Serra Talhada, PE, Brazil; falkner.agro@hotmail.com - ORCID: 0000-00020680-3096.

${ }^{3}$ Agronomic Engineering Course, Instituto Federal de Alagoas, Piranhas, AL, Brazil; enio.souza@ifal.edu.br - ORCID: 0000-0003-43553388 .

${ }^{4}$ Center for Agrarian Sciences, Department of Agronomic and Forest Sciences, Universidade Federal Rural do Semi-Árido, Mossoró, RN, Brazil; manoel.galdino5@gmail.com - ORCID: 0000-0003-4972-5849, aurelio.barros@ufersa.edu.br - ORCID: 0000-0002-6983-8245, hamurabia@hotmail.com - ORCID: 0000-0002-4548-9108.

${ }^{5}$ Agência Estadual de Pesquisa Agropecuária e de Extensão Rural do Maranhão, Chapadinha, MA, Brazil; francilene67@yahoo.com.br ORCID: 0000-0003-2133-0140.
} 


\section{INTRODUCTION}

Beet (Beta vulgaris L.; Quenopodiaceae) is one of the most important vegetables in Brazil. According to the Companhia Nacional de Abastecimento (CONAB, 2020), 112,993,960 kg of beet were traded in 2019 in food supply centers in the country, generating a revenue of US\$ $99,215,624.37$, with an average price of US\$ $0.87 \mathrm{~kg}^{-1}$. Beet is widely grown throughout the country, presenting a better crop development in regions with mild or low temperatures, close to $20{ }^{\circ} \mathrm{C}$.

However, high crop yield and quality requires correct monitoring and management of all production stages; thus, a proper management of soil organic and mineral fertilizers is essential. Beet is a crop that demands balanced fertilization. According to Grangeiro et al. (2007), the decreasing order of nutrients accumulated by beet plants is nitrogen $(\mathrm{N})$, potassium $(\mathrm{K})$, magnesium $(\mathrm{Mg})$, calcium $(\mathrm{Ca})$, and phosphorus $(\mathrm{P})$.

In recent years, the use of green manure has gained prominence. This practice consists of incorporating plant biomasses rich in nutrients into the soil, which improves the soil physical, chemical, and biological characteristics, and consequently, soil fertility and conservation. In addition, green manure adds organic matter, which favors soil aggregation and water retention capacity, reduces erosion rates, increases soil microbiota activity, and promotes nutrient availability (NASCIMENTO; MATTOS, 2007; MORAES et al., 2019).

Spontaneous plants from the Caatinga biome in the semiarid region of the Northeast of Brazil present several desirable characteristics for use as green manure. Among these plants, Jitirana (Merremia aegyptia L.), Mata-pasto (Senna uniflora L.), and Roostertree [Calotropis procera (Ait.) $\mathrm{R}$. Br.] stand out due to their availability, ease of obtaining, high fresh mass production, and high $\mathrm{N}$ contents (BATISTA et al., 2016). Some studies have been conducted using these species, which have shown good results as soil fertilizers for leafy and root vegetables and increased commercial yields for single crops (GÓES et al., 2011; SILVA et al., 2011; BEZERRA NETO et al., 2014; OLIVEIRA et al., 2015a; SOUZA et al., 2016; SOUZA et al., 2017; SILVA et al., 2017; SOUZA et al., 2019; NUNES et al., 2020) and intercrops (ALMEIDA et al., 2015; OLIVEIRA et al., 2015b; BEZERRA NETO et al., 2019).

C. procera plants have stood out among other plants studied as green manure due to their high resistance to drought and development throughout the year. This species also has high regrowth capacity after cut, emitting large number of vigorous leaves and presenting high accumulation of biomass, which is rich in N (ANDRADE et al., 2008). Studies have reported economic viability of the use of $C$. procera plants as green manure for radish (SILVA et al., 2015) and rocket (SOUZA et al., 2015) crops.

In this context, the objective of this work was to evaluate the effects of different amounts of biomass of Calotropis procera plants (roostertree) and incorporation times on the agro-economic performance of beet crops grown in Serra Talhada, state of Pernambuco, Brazil.

\section{MATERIAL AND METHODS}

The experiments were carried out at the Universidade Federal Rural de Pernambuco (UFRPE), in Serra Talhada, Pernambuco, Brazil ( $7^{\circ} 57^{\prime} 15^{\prime \prime S}, 38^{\circ} 17^{\prime} 41^{\prime \prime} \mathrm{W}$, and $461 \mathrm{~m}$ altitude), in two growing seasons: autumn (March 27 to June 20, 2012) and spring-summer (October 31 to January 19, 2013). The region presents a Bwh, semiarid, hot and dry climate, according to the Köppen classification, with a rainy summer, mean annual temperature of $24.7{ }^{\circ} \mathrm{C}$, and mean annual rainfall depth of $642.10 \mathrm{~mm}$.

The soil of the experimental area had a sandy loam texture, with total porosity of $47.58 \%$. The soil chemical characteristics $(0-0.20 \mathrm{~m}$ layer) before the experiments were: $\mathrm{pH}=7.2 ; \mathrm{P}=14.0 \mathrm{mg} \mathrm{dm}^{-3} ; \mathrm{K}^{+}=$ $0.55 \mathrm{cmol}_{\mathrm{c}} \mathrm{dm}^{-3} ; \mathrm{Al}^{3+}=0.0 \mathrm{cmol}_{\mathrm{c}} \mathrm{dm}^{-3} ; \mathrm{Ca}^{2+}=$ $3.90 \mathrm{cmol}_{\mathrm{c}} \mathrm{dm}^{-3} ; \mathrm{Mg}^{2+}=1.20 \mathrm{cmol}_{\mathrm{c}} \mathrm{dm}^{-3}$ in the autumn season; and $\mathrm{pH}=6.6 ; \mathrm{P}=150 \mathrm{mg} \mathrm{dm}^{-3} ; \mathrm{K}^{+}=$ $0.69 \mathrm{cmol}_{\mathrm{c}} \mathrm{dm}^{-3} ; \mathrm{Al}^{3+}=0.0 ; \mathrm{Ca}^{2+}=3.40 \mathrm{cmol}_{\mathrm{c}} \mathrm{dm}^{-3}$; $\mathrm{Mg}^{2+}=2.0 \mathrm{cmol}_{\mathrm{c}} \mathrm{dm}^{-3}$; in the spring-summer season.

A randomized block experimental design was used, with three replications, in a $4 \times 4$ factorial arrangement; the first factor consisted of four amounts of $C$. procera biomass $(5.4,8.8,12.2$, and $15.6 \mathrm{Mg} \mathrm{ha}^{-1}$ on a dry basis) and the second factor consisted of four times of incorporation into the soil $(0,10,20$, and 30 days before planting beet).

The experimental plots had an area of $1.44 \mathrm{~m}^{2}$, with an evaluation area of $0.80 \mathrm{~m}^{2}$. Six plant rows were arranged transversely in each plot, with spacing of $0.20 \mathrm{~m} \times 0.10 \mathrm{~m}$. The beet cultivar used was the Early Wonder (AGRISTAR, 2021), which is recommended for the semiarid conditions of the Northeast of Brazil. The soil preparation for both experiments consisted of raising the beds using hoes.

C. procera plants were collected from a native vegetation area close to the Unidade Acadêmica de Serra Talhada (UAST). The plants were crushed in a conventional forage cutter, obtaining fragments between 2.0 to $3.0 \mathrm{~cm}$, which were dried until reaching $10 \%$ moisture, stored as hay, and used for both experiments. The hay 
obtained from $C$. procera plants presented the following nutrient contents: $\mathrm{N}=17.4 \mathrm{~g} \mathrm{~kg}^{-1} ; \mathrm{P}=$ $4.4 \mathrm{~g} \mathrm{~kg}^{-1} ; \mathrm{K}=23.5 \mathrm{~g} \mathrm{~kg}^{-1} ; \mathrm{Ca}=14.3 \mathrm{~g} \mathrm{~kg}^{-1} ; \mathrm{Mg}=$ $23.0 \mathrm{~g} \mathrm{~kg}^{-1} ; \mathrm{Fe}=463.0 \mathrm{mg} \mathrm{kg}{ }^{-1}, \mathrm{Zn}=40.0 \mathrm{mg} \mathrm{kg}^{-1}$; $\mathrm{Cu}=29 \mathrm{mg} \mathrm{kg}^{-1} ; \mathrm{Mn}=90 \mathrm{mg} \mathrm{kg}^{-1} ; \mathrm{B}=71 \mathrm{mg} \mathrm{kg}^{-1}$; $\mathrm{Na}=1,640.00 \mathrm{mg} \mathrm{kg} \mathrm{kg}^{-1}$, organic matter = $764.0 \mathrm{mg} \mathrm{kg}^{-1} ; \mathrm{C} / \mathrm{N}=25 / 1$.

The plant biomass was manually incorporated into the $0-0.20 \mathrm{~m}$ soil layer of the experimental plots with the aid of a hoe, according to the treatments. Mineral fertilizers were not applied. The soil was irrigated in two daily shifts to favor the soil microbial activity for organic matter mineralization.

Beet propagules were planted on March 27, 2012 for the first growing season (autumn), and on October 31, 2012 for the second growing season (spring-summer), directly to the soil, at two centimeters depth, using three propagules per pit. A thinning was carried out at ten days after emergence, leaving one plant per hole. Manual weeding was carried out as needed.

The autumn beet harvest was carried out at 85 days after planting, and the spring-summer harvest was carried out at 80 days after planting. The commercial root yield of plants in the evaluation area were estimated $\left(\mathrm{Mg} \mathrm{ha}^{-1}\right)$ considering a correction for $70 \%$ of the area actually planted. Economic indicators were used to assess the efficiency of the treatments. The production costs for the municipality of Serra Talhada in 2012 were estimated and analyzed at the end of the production process, according to the methodology described by Souza et al. (2015).

Gross income (GI) was measured using the values of the production per hectare in June 2012 (US\$ $0.76 \mathrm{~kg}^{-1}$ ) and January 2013 (US\$ $1.01 \mathrm{~kg}^{-1}$ ). Net income (NI) was calculated through the difference between the gross income (GI) per hectare and the total production costs (TC). The TC were calculated for each treatment, considering the cost coefficients of inputs and services used in one hectare of beet at experimental level. The rate of return was obtained by the ratio between GI and TC, representing how many dollars are obtained per dollar invested in the beet crop, according to the treatment applied. The profitability index (PI) consisted of the ratio between NI and GI, which were expressed as a percentage (BEZERRA NETO et al., 2010).

The results of the evaluated characteristics were subjected to analysis of variance (ANOVA) for each growing season, using the SISVAR program (FERREIRA, 2011). A joint analysis was carried out for the characteristics that presented homogeneity of variance between growing seasons. Response curves were determined for the evaluated characteristics in each treatment.

\section{RESULTS AND DISCUSSION}

The results of the joint analysis of the variables evaluated, according to growing season, amount of biomass of $C$. procera plants, and time of incorporation of biomass into the soil, showed that the interaction between the three factors was significant for all characteristics evaluated.

The commercial production of beet roots showed increases in yield as the amount of $C$. procera biomass incorporated into the soil was increased, regardless of the other factors evaluated (Figures 1A and 1B). In the autumn season (Figure 1A), the treatment with addition of $14.23 \mathrm{Mg} \mathrm{ha}^{-1}$ of biomass to the soil at 10 days before planting (DBP) the beet crop resulted in the highest commercial beet root yield $\left(35.53 \mathrm{Mg} \mathrm{ha}^{-1}\right.$ ). In the spring-summer season, the highest estimated commercial beet root yield was $33.78 \mathrm{Mg} \mathrm{ha}^{-1}$ for the highest rate of $C$. procera biomass (15.6 $\mathrm{Mg} \mathrm{ha}^{-1}$ ) applied on the day of planting (Figure 1B), followed by the treatments with biomass incorporation into the soil at $10 \mathrm{DBP}$ (29.52 $\left.\mathrm{Mg} \mathrm{ha}^{-1}\right), 20 \mathrm{DBP}$ (28.54 Mg ha $\mathrm{Mg}^{-1}$, and 30 DBP (26.96 $\mathrm{Mg} \mathrm{ha}^{-1}$ ) using the highest biomass rate.

These results are related to a great availability of nutrients released by $C$. procera biomass and the simultaneity in which the elements are released and absorbed by the plants with no losses by leaching. However, they may also be due to increases in organic matter and phosphorus contents as the rate of incorporated biomass was increased (BATISTA et al., 2016).

In general, when the green manure stayed longer in the soil, before planting the beet crop, the commercial beet root yield was lower (Figures 1C and 1D). The incorporation of $15.6 \mathrm{Mg} \mathrm{ha}^{-1}$ of biomass into the soil on the day of planting the crop resulted in higher commercial root yields, with statistically equal yields for the autumn $(34.43 \mathrm{Mg}$ $\mathrm{ha}^{-1}$ ) and spring-summer (32.80 $\left.\mathrm{Mg} \mathrm{ha}^{-1}\right)$ growing seasons.

These results can be explained by the fact that beet has a higher nutrient requirement from 30 to 60 days after planting (GRANGEIRO et al., 2007), and that the $C$. procera has a low $\mathrm{C}$ to $\mathrm{N}$ ratio $(25 / 1)$ and most of its nutrients, mainly $\mathrm{N}$, is mineralized within 40 to 45 days after the incorporation of $C$. procera biomass into the soil (TORRES et al., 2005). 
Autumn

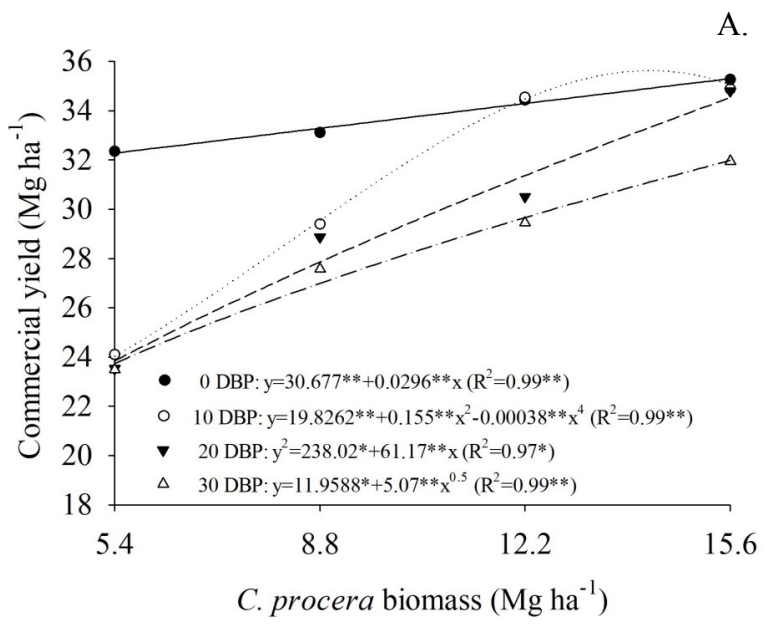

C.

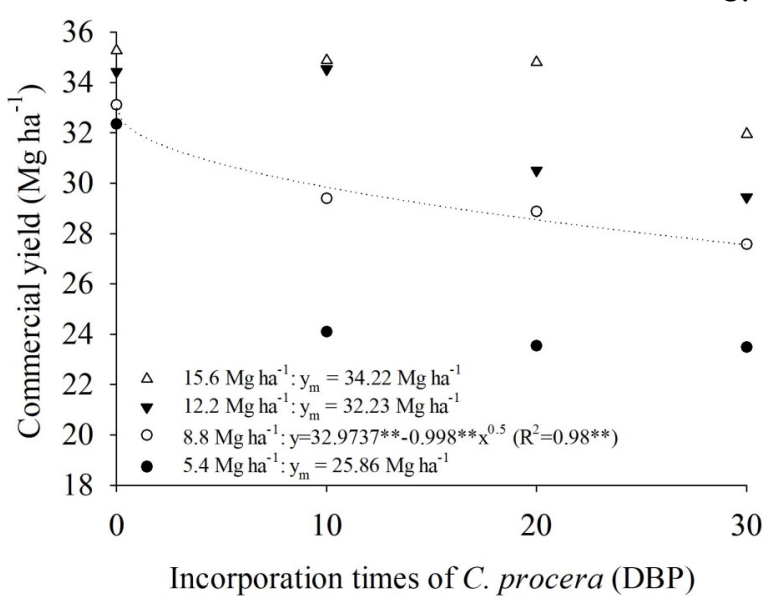

Spring-summer

B.
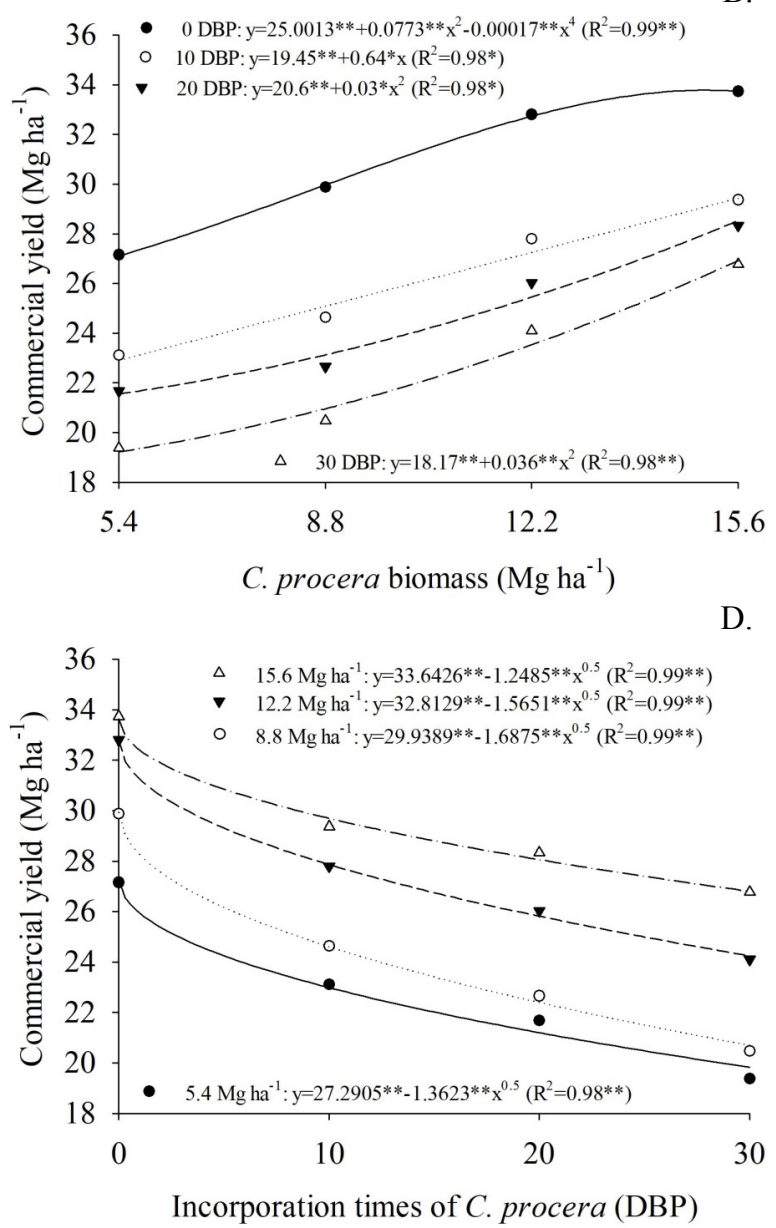

Figure 1. Commercial yield of beet roots as a function of application of different amounts of biomass of Calotropis procera in the Autumn (A) and Spring-summer (B) growing seasons, and different times of biomass incorporation (days before planting - DBP) in the Autumn (C) and Spring-summer (D) growing seasons.

The gross income showed similar results to those found for commercial beet productions, i.e., increasing the amounts of green manure (C. procera) applied to the soil increased the gross income, and the highest values were found with biomass incorporation on the day of planting the beet, in both growing seasons (Figure 2). The biomass rate of 15.6 $\mathrm{Mg} \mathrm{ha}^{-1}$ incorporated on the day of planting provided an average gross income of US\$ 26,877.43 $\mathrm{ha}^{-1}$ in the autumn and US\$ $34,304.90 \mathrm{ha}^{-1}$ in springsummer season, which differed statistically, mainly, due to the price paid for the product in each season: US\$ 0.76 and US\$ $1.01 \mathrm{~kg}^{-1}$, respectively.

Oliveira et al. (2012) found positive effects of green manure from spontaneous species of the Caatinga biome on radish crops, with the highest gross income found when using the greatest amount (15.6 $\mathrm{Mg} \mathrm{ha}^{-1}$ ) of Merremia aegyptia incorporated into the soil. In addition, Oliveira et al. (2015a) found increases in gross income for arugula crops as the rates of $C$. procera was increased.

The sum of variable, fixed, and opportunity costs was US\$ 5,965.68 $\mathrm{ha}^{-1}$ (autumn) and US\$ $5,994.11 \mathrm{ha}^{-1}$ (spring-summer) (Table 1). The total production cost per hectare of beet using $C$. procera plants as green manure was estimated for each amount of biomass incorporated into the soil. The results found for the biomass rates of 5.4, 8.8, 12.2, and $15.6 \mathrm{Mg} \mathrm{ha}^{-1}$ were US\$ 6,615.93 $\mathrm{ha}^{-1}$, US\$ $7,039.71 \mathrm{ha}^{-1}$, US\$ 7,465.02 $\mathrm{ha}^{-1}$, and US\$ 7,888.81 $\mathrm{ha}^{-1}$ for the autumn, and US\$ 6,644.36 ha-1, US\$ $7,064.14 \mathrm{ha}^{-1}$, US\$ 7,493.45 $\mathrm{ha}^{-1}$, and US\$ 7,917.23 $\mathrm{ha}^{-1}$ for the spring-summer growing season, respectively (Table 2). The difference between production costs was due to differences in the costs of cutting, transport, crushing, drying, bagging, distribution, and incorporation of $C$. procera plants and electrical energy (forage cutter), which increased as the amount of incorporated biomass was increased. 
Autumn



C.

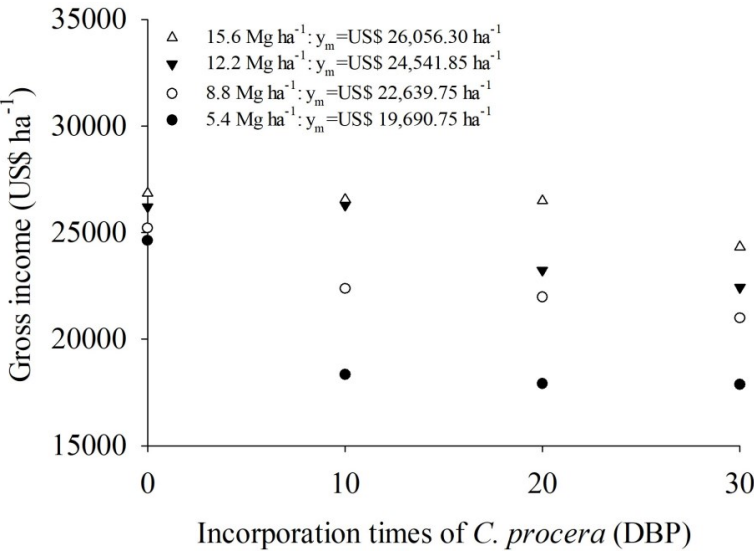

Spring-summer

B.
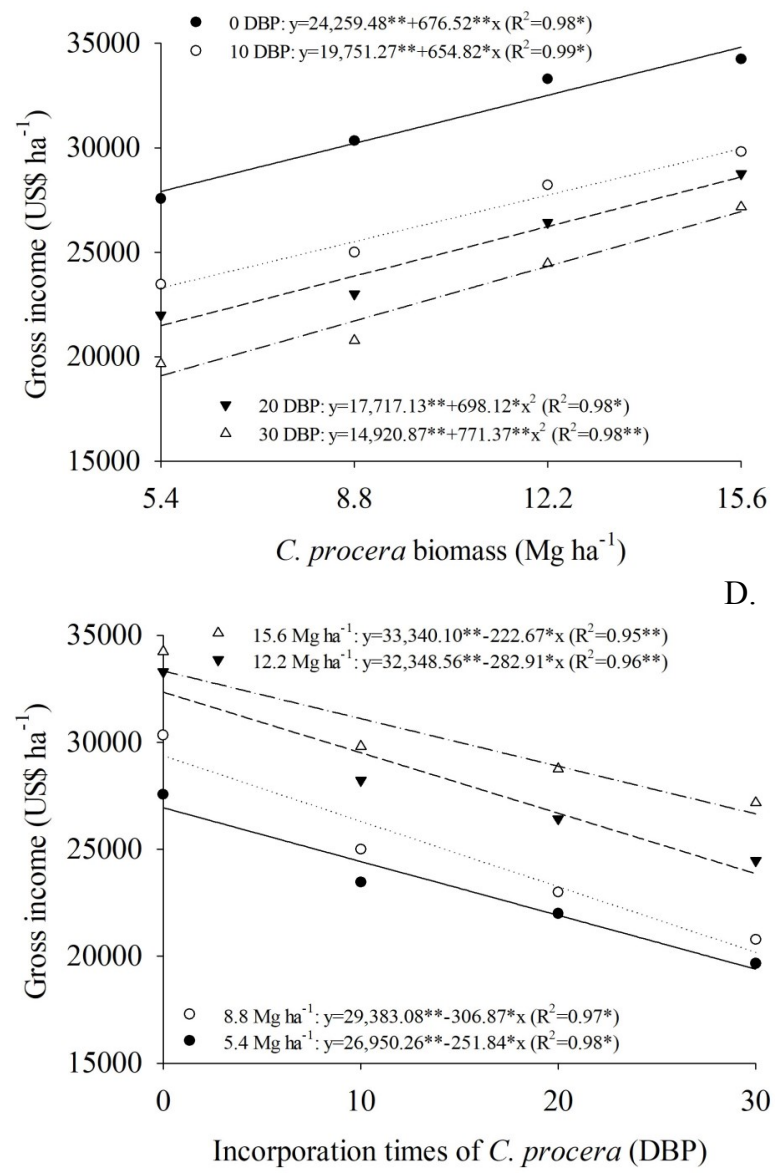

Figure 2. Gross income (US\$ ha ${ }^{-1}$ ) from beet production as a function of application of different amounts of biomass of Calotropis procera in the Autumn (A) and Spring-summer (B) growing seasons, and different times of biomass incorporation (days before planting - DBP) in the Autumn (C) and Spring-summer (D) growing seasons.

Table 1. Coefficients of variable, fixed, and opportunity costs to produce one hectare of beet, in two growing seasons.

\begin{tabular}{|c|c|c|c|c|c|}
\hline \multirow[b]{2}{*}{ Components of Production Costs } & \multirow[b]{2}{*}{ Unity } & & \multirow[b]{2}{*}{ Amount } & \multicolumn{2}{|c|}{ Total (US\$) } \\
\hline & & & & Autumn & $\begin{array}{l}\text { Spring/ } \\
\text { summer }\end{array}$ \\
\hline Variable costs & & & & $4,085.48$ & $4,085.48$ \\
\hline 1 - Inputs & & & & 571.07 & 571.07 \\
\hline Seeds: Beet cv. Early Wonder & & $\mathrm{kg}$ & 15.0 & 571.07 & 571.07 \\
\hline 2 - Labor & & & & $3,350.25$ & $3,350.25$ \\
\hline Raising of beds & & daily & 40 & 609.14 & 609.14 \\
\hline Beet planting & & daily & 30 & 456.85 & 456.85 \\
\hline Beet thinning & & daily & 15 & 228.43 & 228.43 \\
\hline Manual weeding & & daily & 15 & 228.43 & 228.43 \\
\hline Heap & & daily & 20 & 304.57 & 304.57 \\
\hline Irrigation & & daily & 45 & 685.28 & 685.28 \\
\hline Beet harvest & & daily & 50 & 761.42 & 761.42 \\
\hline Beet transport & & daily & 5 & 76.14 & 76.14 \\
\hline $3-$ Energy & & & & 164.16 & 164.16 \\
\hline Energy used for irrigation & & $\mathrm{kW}$ & 1470.0 & 164.16 & 164.16 \\
\hline Fixed Costs & & & & $1,575.63$ & $1,604.06$ \\
\hline
\end{tabular}

*Ratio between market value and useful life of the equipment multiplied by the use time; ** Value of fixed capital (US\$ 10,152.28 $\mathrm{ha}^{-1}$ ) multiplied by its possible remuneration throughout the crop period. 
F. M. S. SANTANA et al.

Table 1. Continuation.

\begin{tabular}{|c|c|c|c|c|}
\hline \multirow[b]{2}{*}{ Components of Production Costs } & \multirow[b]{2}{*}{ Unity } & \multirow[b]{2}{*}{ Amount } & \multicolumn{2}{|c|}{ Total (US\$) } \\
\hline & & & Autumn & $\begin{array}{c}\text { Spring/ } \\
\text { summer }\end{array}$ \\
\hline 4 - Depreciation & & & 307.61 & 307.61 \\
\hline Irrigation pump & month* & 4 & 116.75 & 116.75 \\
\hline Irrigation pipes & month & 4 & 7.11 & 7.11 \\
\hline Connections & month & 4 & 26.40 & 26.40 \\
\hline Micro sprinklers & month & 4 & 81.22 & 81.22 \\
\hline Forage cutter & month & 1 & 76.14 & 76.14 \\
\hline $5-$ Taxes and fees & & & 5.08 & 5.08 \\
\hline Rural land tax & ha & 1 & 5.08 & 5.08 \\
\hline $6-$ Fixed labor & & & $1,262.94$ & $1,291.37$ \\
\hline Administrative Assistant & salary & 4 & $1,262.94$ & $1,291.37$ \\
\hline Opportunity Costs & & & 304.57 & 304.57 \\
\hline 7 - Land remuneration & & & 101.52 & 101.52 \\
\hline Rent & ha & 1 & 101.52 & 101.52 \\
\hline $8-$ Remuneration of fixed capital $(0.5$ & & & 203.05 & 203.05 \\
\hline Infrastructure and equipment & $\begin{array}{l}\text { US\$ } 50.76 \\
\text { month }^{-1} * *\end{array}$ & 4 & 203.05 & 203.05 \\
\hline Total (Variable costs + Fixed costs $+C$ & $\mathrm{y}$ costs) & & $5,965.68$ & $5,994.11$ \\
\hline
\end{tabular}

*Ratio between market value and useful life of the equipment multiplied by the use time; ** Value of fixed capital (US\$ $10,152.28 \mathrm{ha}^{-1}$ ) multiplied by its possible remuneration throughout the crop period.

Table 2. Total costs to produce one hectare of beet grown using different amounts of Calotropis procera plants as green manure, in two growing seasons.

\begin{tabular}{|c|c|c|c|c|}
\hline \multirow[b]{2}{*}{ Components of Production Costs } & \multirow[b]{2}{*}{ Unit } & \multirow[b]{2}{*}{ Amount } & \multicolumn{2}{|c|}{ Total (US\$) } \\
\hline & & & Autumn & $\begin{array}{l}\text { Spring/ } \\
\text { summer }\end{array}$ \\
\hline $1-5.4 \mathrm{Mg} \mathrm{ha}^{-1}$ in C. procera & & & $6,615.94$ & $6,644.37$ \\
\hline Cut & daily & 20.0 & 304.57 & 304.57 \\
\hline Transport & freight & 1.0 & 40.61 & 40.61 \\
\hline Crushing & daily & 2.5 & 38.07 & 38.07 \\
\hline Electrical energy (forage cutter) & $\mathrm{kW}$ & 100 & 11.17 & 11.17 \\
\hline Drying & daily & 5.0 & 76.14 & 76.14 \\
\hline Bagging & daily & 1.0 & 15.23 & 15.23 \\
\hline Distribution and incorporation & daily & 10.8 & 164.47 & 164.47 \\
\hline Variable, fixed, and opportunity costs & & & $5,965.69$ & $5,994.11$ \\
\hline $2-8.8 \mathrm{Mg} \mathrm{ha}^{-1}$ in C. procera & & & $7,039.72$ & $7,068.14$ \\
\hline Cut & daily & 32.6 & 496.45 & 496.45 \\
\hline Transport & freight & 2.0 & 81.22 & 81.22 \\
\hline Crushing & daily & 4.1 & 62.44 & 62.44 \\
\hline Electrical energy (forage cutter) & $\mathrm{kW}$ & 162.9 & 18.19 & 18.19 \\
\hline Drying & daily & 8.1 & 123.35 & 123.35 \\
\hline Bagging & daily & 1.6 & 24.37 & 24.37 \\
\hline Distribution and incorporation & daily & 17.6 & 268.02 & 268.02 \\
\hline Variable, fixed, and opportunity costs & & & $5,965.69$ & $5,994.11$ \\
\hline $3-12.2 \mathrm{Mg} \mathrm{ha}^{-1}$ in C. procera & & & $7,465.03$ & $7,493.45$ \\
\hline Cut & daily & 45.2 & 688.32 & 688.32 \\
\hline Transport & freight & 3.0 & 121.83 & 121.83 \\
\hline Crushing & daily & 5.6 & 85.28 & 85.28 \\
\hline Electrical energy (forage cutter) & $\mathrm{kW}$ & 225.9 & 25.23 & 25.23 \\
\hline Drying & daily & 11.3 & 172.08 & 172.08 \\
\hline Bagging & daily & 2.3 & 35.03 & 35.03 \\
\hline Distribution and incorporation & daily & 24.4 & 371.57 & 371.57 \\
\hline Variable, fixed, and opportunity costs & & & $5,965.69$ & $5,994.11$ \\
\hline $4-15.6 \mathrm{Mg} \mathrm{ha}^{-1}$ in C. procera & & & $7,888.81$ & $7,917.24$ \\
\hline Cut & daily & 57.8 & 880.20 & 880.20 \\
\hline Transport & freight & 4.0 & 162.44 & 162.44 \\
\hline Crushing & daily & 7.2 & 109.64 & 109.64 \\
\hline Electrical energy (forage cutter) & $\mathrm{kW}$ & 288.9 & 32.26 & 32.26 \\
\hline Drying & daily & 14.4 & 219.29 & 219.29 \\
\hline Bagging & daily & 2.9 & 44.16 & 44.16 \\
\hline Distribution and incorporation & daily & 31.2 & 475.13 & 475.13 \\
\hline Variable, fixed, and opportunity costs & & & $5,965.69$ & $5,994.11$ \\
\hline
\end{tabular}


The green manure cutting and preparation represented $9.8,15.2,20.0$, and $24.3 \%$ of the total costs for the C. procera biomass rates of 5.4, 8.8, 12.2 , and $15.6 \mathrm{Mg} \mathrm{ha}^{-1}$, respectively. The production costs in the spring were higher due to a raise in the wage to the administrative assistant in January 2013 (from US\$ 622.00 to US\$ 678.00). Daily expenses (labor) ranged from 66 to $85 \%$ of the total costs between the lowest and greatest amounts of $C$. procera biomass (Tables 1 and 2). Some studies using this green manure have shown similar results, in which labor was the most expensive operating cost, representing, on average, $68 \%$ of the total costs in radish crops (SILVA et al., 2015) and 69\% in rocket crops (SOUZA et al., 2015).

Production costs include the labor cost, which is the key for a sustainable production for small growers. Thus, costs can be reduced by using family labor for growth and preparation of green manure in the property, reducing transport costs.

The estimated highest net income was US\$ $19,316.28 \mathrm{ha}^{-1}$ in the autumn growing season, with $14.16 \mathrm{Mg} \mathrm{ha}^{-1}$ of $C$. procera biomass incorporated at 10 days DBP (Figures 3A and 3C). In the springsummer growing season, the biomass rate of 15.6 $\mathrm{Mg} \mathrm{ha}^{-1}$, incorporated on the day of planting resulted in a net income of US\$ 26,329.80 $\mathrm{ha}^{-1}$ (Figures 3B and 3D).

Despite these similar high results in gross income (commercial yield) between growing seasons, different remunerations for the product were found. In addition, the growing seasons had little impact on the total production costs (Tables 1 and 2). Thus, a relative increase of $36.3 \%$ in net income was found for the spring-summer over the autumn growing season.
Autumn

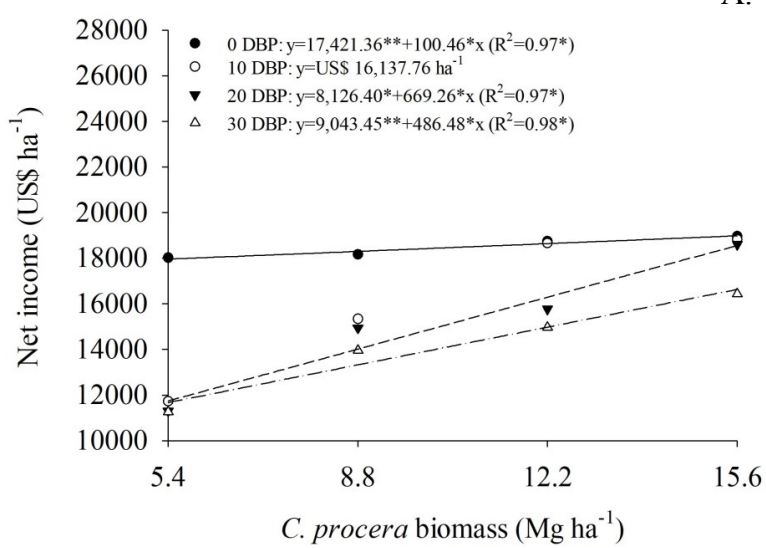

C.

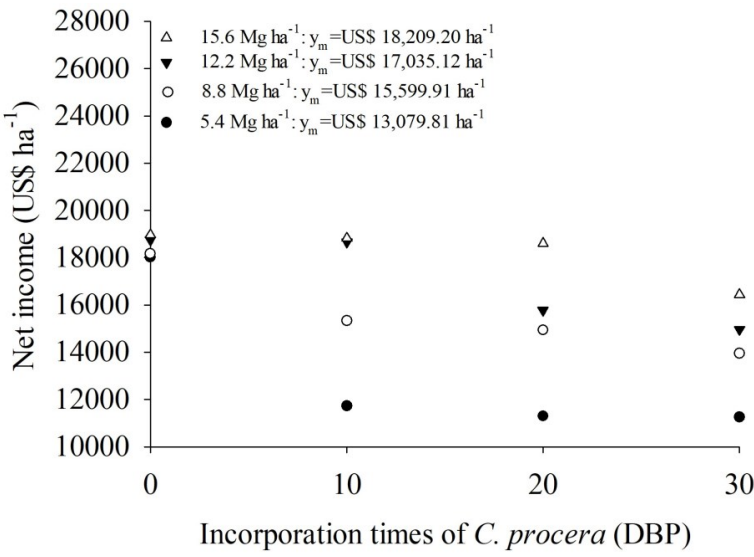

Spring-summer

B.
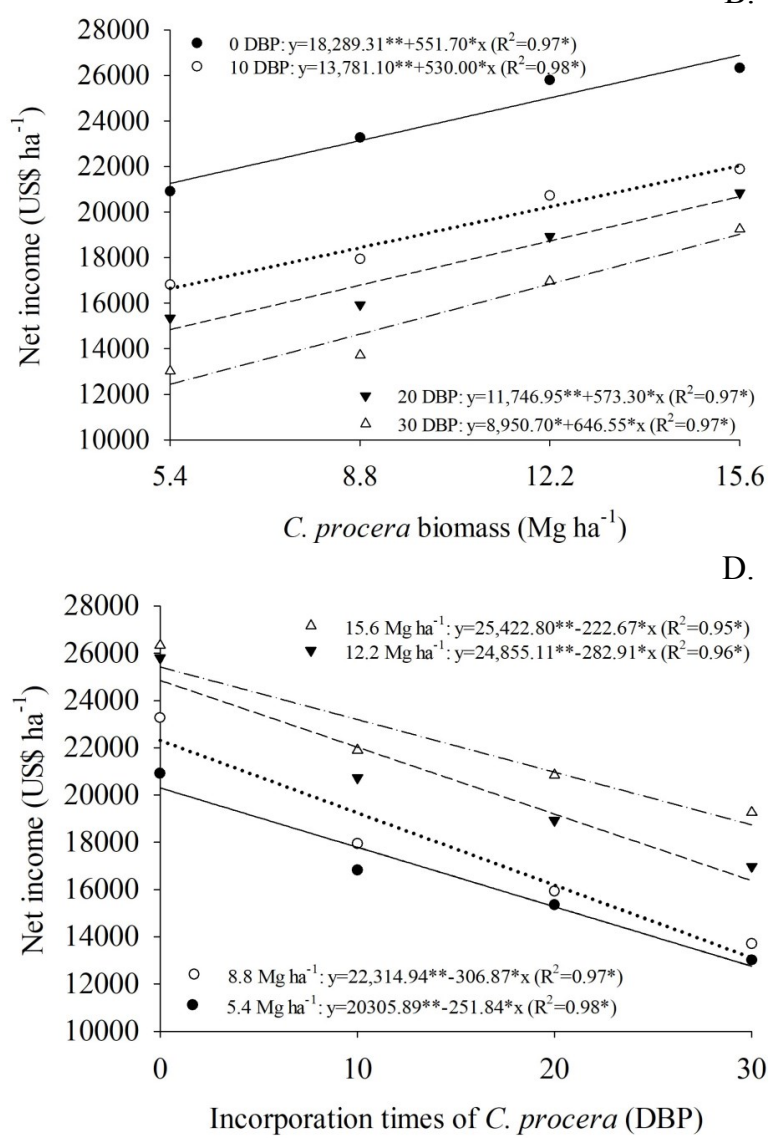

Figure 3. Net income (US\$ ha ${ }^{-1}$ ) from beet crops as a function of application of different amounts of biomass of Calotropis procera in the Autumn (A) and Spring-summer (B) growing seasons, and different times of biomass incorporation (days before planting - DBP) in the Autumn (C) and Spring-summer (D) growing seasons.

In the autumn, the incorporation of $5.4 \mathrm{Mg} \mathrm{ha}{ }^{-1}$ of biomass on the day of planting resulted in the highest rate of return (3.71) (Figures 4A and 4C). This better result when using the lower green manure rate is explained by the high commercial root yield $\left(32.05 \mathrm{Mg} \mathrm{ha}{ }^{-1}\right)$ and the reduced cost to obtain and incorporate the $C$. procera biomass (US\$ $650.25 \mathrm{ha}^{-1}$ ). This yield was only $9 \%$ 
lower than that found when using $15.6 \mathrm{Mg} \mathrm{ha}^{-1}$

In the spring-summer, the highest estimated rate of return was US\$2.25 per dollar invested when incorporating $12.7 \mathrm{Mg} \mathrm{ha}^{-1}$ of biomass into the soil on the day of planting the beet crops (Figures $4 \mathrm{~B}$ and 4D). These results denote the high commercial root yield achieved when incorporating $12.7 \mathrm{Mg} \mathrm{ha}^{-1}$ of biomass into the soil on the day of planting, resulting in an increase in gross income, which is connected to a labor cost lower than that found using the greatest amount of $C$. procera biomass. The spring-summer showed a higher rate of return than the autumn growing season due to a higher crop yield (33.33\%); however, the commercial root yield and production costs varied little between growing seasons.
Autumn
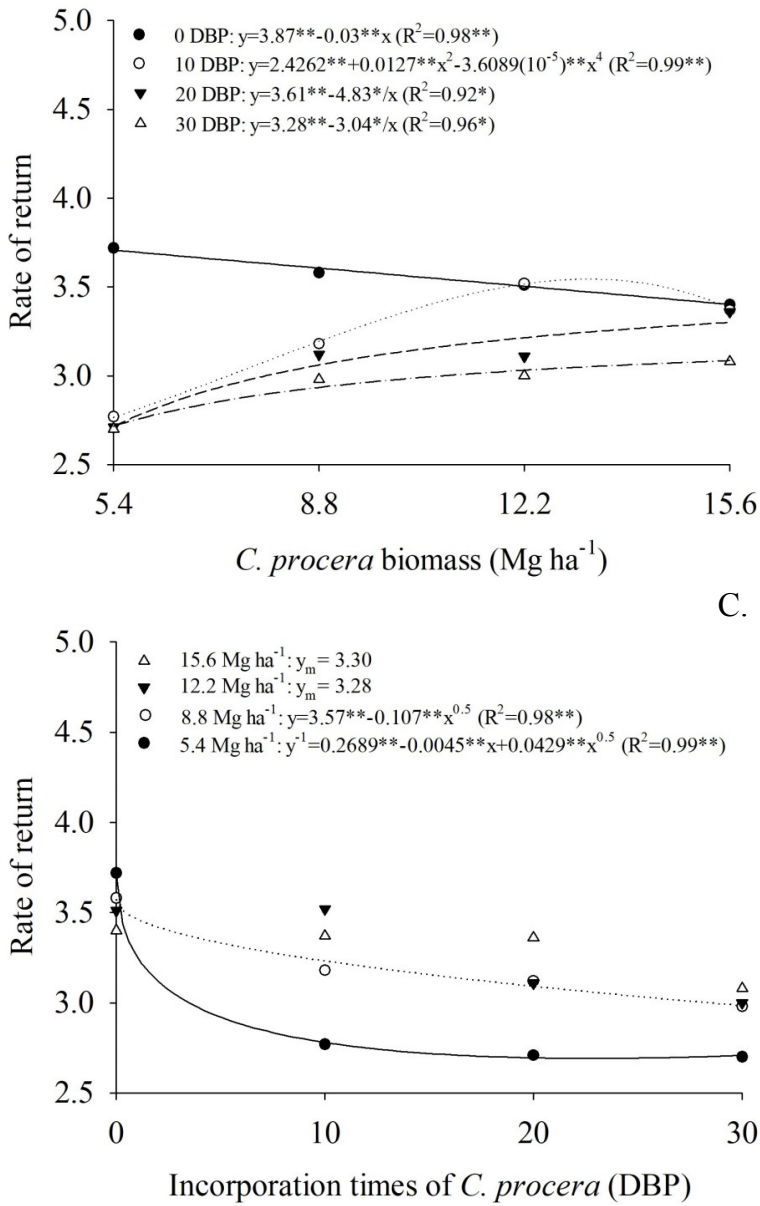

Spring-summer
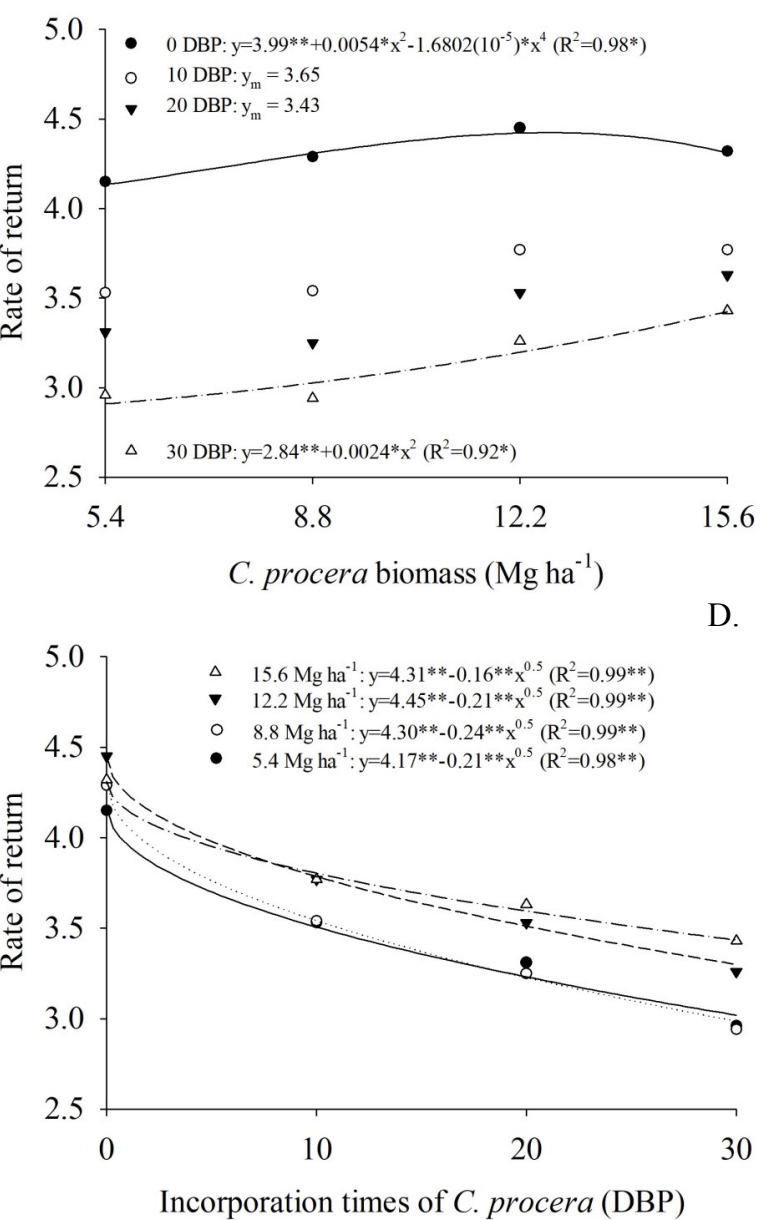

Figure 4. Rate of return to produce one hectare of beet as a function of application of different amounts biomass of Calotropis procera in the Autumn (A) and Spring-summer (B) growing seasons, and different times of biomass incorporation (days before planting - DBP) in the Autumn (C) and Spring-summer (D) growing seasons.

Silva et al. (2015) evaluated the economic viability of radish crops for Serra Talhada using $C$. procera biomass as green manure and found a higher rate of return in the spring-summer when compared to that found in the autumn growing season. The Semiarid region of Pernambuco usually presents rainfall events in late summer, which fills reservoirs and enables the planting of vegetables in the autumnwinter seasons, consequently, increasing the supply and decreasing prices of these products. In the second half of the year, occurrences of high temperatures and droughts restrict vegetable production to a few rural areas, which have greater water security. This situation usually increases the price of vegetables in the spring.

Oliveira et al. (2015a) evaluated increasing rates of $C$. procera for arugula crops in the springsummer growing season and found a rate of return of 1.83 per dollar invested when incorporating the greatest amount $\left(70 \mathrm{Mg} \mathrm{ha}^{-1}\right)$ of the green manure. 
Bezerra Neto et al. (2014) evaluated carrot crops using $13 \mathrm{Mg} \mathrm{ha}^{-1}$ of $M$. aegyptia biomass incorporated into the soil $(50 \%$ at 20 , and $50 \%$ at 55 days after planting) and the highest rate of return found was US\$ 1.00 per dollar invested. This low value compared to that found in the present study may be related to the price paid for the product (US\$ $0.41 \mathrm{~kg}^{-1}$ ), which results in a lower gross income, which is directly related to the rate of return.

The profitability index had similar results to those found for the rate of return, i.e., the values decreased in the autumn growing season as the amount of $C$. procera biomass and incorporation time were increased. The amount of $5.4 \mathrm{Mg} \mathrm{ha}^{-1}$ of C. procera incorporated on the day of planting resulted in the highest profitability index, $73.1 \%$ (Figures 5A and 5C). In the spring-summer growing season, the profitability index also decreased as the time of biomass incorporation was increased, but reached the highest value $(77.4 \%)$ with $12.8 \mathrm{Mg} \mathrm{ha}^{-1}$ of $C$. procera incorporated into the soil on the day of planting the crop (Figures 5B and 5D). The profitability index found in the spring-summer growing season was higher than that found in the autumn, presenting similarity to the other economic indicators.

\section{Autumn}

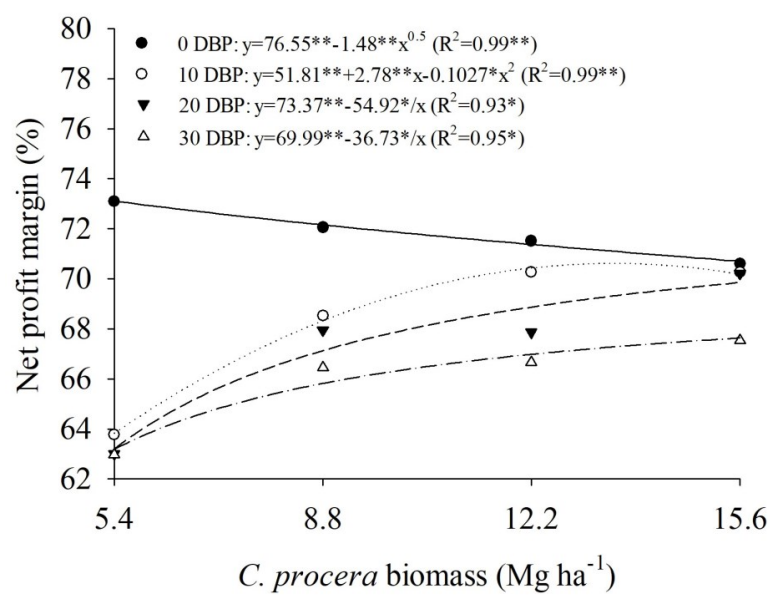

C.

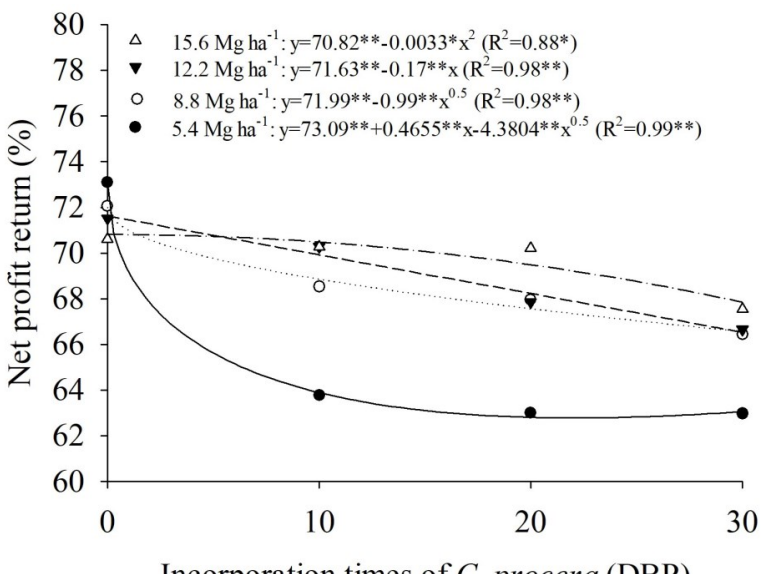

Incorporation times of $C$. procera (DBP)
Spring-summer
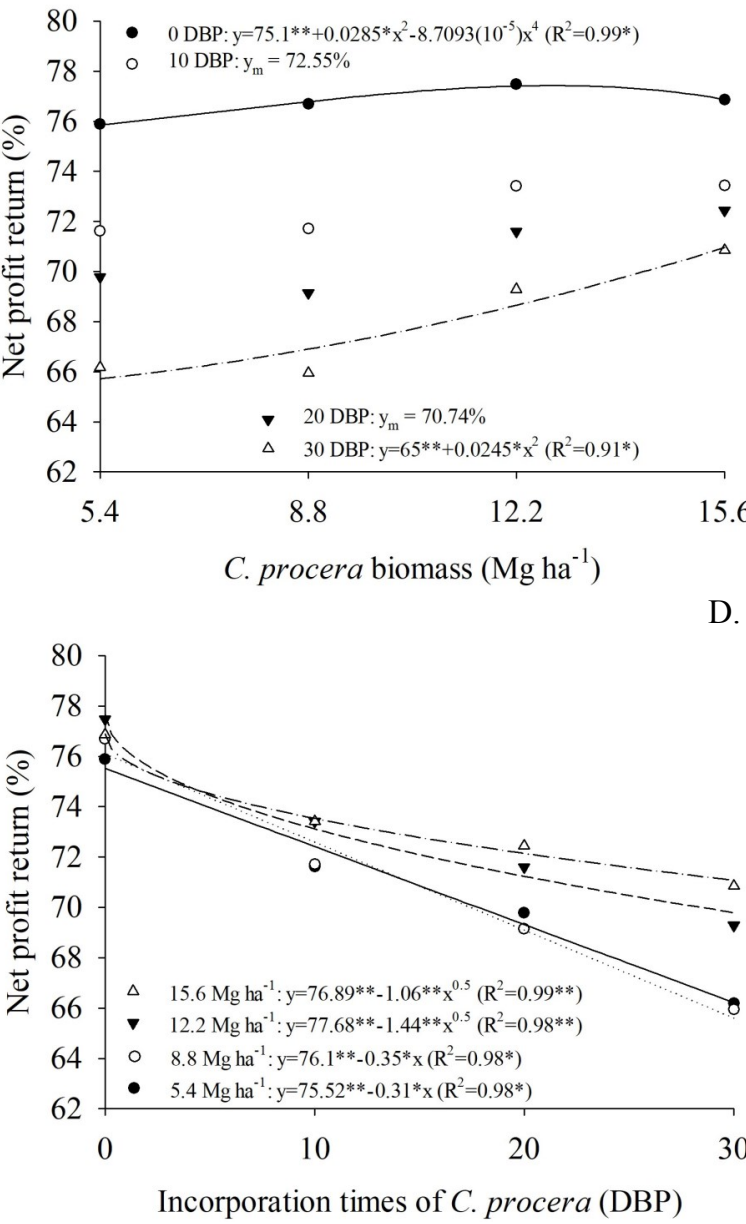

Figure 5. Profitability index (\%) to produce one hectare of beet as a function of application of different amounts of Calotropis procera biomass in the Autumn (A) and Spring-summer (B) growing seasons, and different times of biomass incorporation (days before planting - DBP) in the Autumn (C) and Spring-summer (D) growing seasons.

The results of the present study showed similar profitability indexes to those found in studies using C. procera as green manure for radish (SILVA et al., 2015) and rocket (OLIVEIRA et al., 2015a; SOUZA et al., 2015) crops. These results denote that beet crops respond well to this green manure, improving the commercial root yield and the profitability of the investment due to reductions in production costs. In addition, organic inputs allow for a better use of local environmental resources, 
reducing the dependence on external inputs.

In general, the beet crops were agronomically and economically viable in both growing seasons evaluated, presenting satisfactory results even for the lowest amounts of $C$. procera biomass used. Thus, this green manure proved to be a good option as soil organic fertilizer for family farmers in the Semiarid region of Brazil because of its high rusticity and high biomass production throughout the year.

\section{CONCLUSIONS}

Beet crops grown in soils fertilized with biomass of Calotropis procera are economically viable, regardless of the amount of green manure, time of incorporation of biomass into the soil, and growing season. The highest profitability of the beet crop was found when added to the soil biomass rates of $5.4 \mathrm{Mg} \mathrm{ha}^{-1}$ (autumn growing season) and 12.2 $\mathrm{Mg} \mathrm{ha}^{-1}$ (spring-summer growing season) on the day of planting the crop. The rate of return and profitability index of beet crops fertilized with $C$. procera biomass were higher in the spring-summer when compared to the autumn growing season.

\section{ACKNOWLEDGEMENTS}

To the Instituto Federal de Alagoas, for granting financial assistance for the publication of this scientific article (Public Notice $n^{\circ} 12 / 2021$, of 06/15/2021).

\section{REFERENCES}

AGRISTAR. Beterraba Early Wonder. 2021. Available in: <https://agristar.com.br/topseedpremium/beterraba/early-wonder-2000/1358//>. Access in: 13 may. 2021.

ALMEIDA, A. E. S. et al. Agronomic efficiency of the intercropping lettuce-arugula fertilized with roostertree. Revista Caatinga, 28: 79-85, 2015.

ANDRADE, M. V. M. D. et al. Productivity and quality of rooster tree in different planting densities and planting systems. Revista Brasileira de Zootecnia, 37: 1-8, 2008.

BATISTA, M. A. et al. Soil-plant attributes and beet production influenced by fertilization with species of Brazilian Caatinga. Horticultura Brasileira, 34: 3138, 2016.

BEZERRA NETO, F. et al. Agronomic and economic optimization of the carrot when fertilized with different dosages of jitarana. Ciência
Agronômica, 45: 305-311, 2014.

BEZERRA NETO, F. et al. Evaluation of yield advantage indexes in carrot-lettuce intercropping systems. Interciencia, 35: 59-64, 2010.

BEZERRA NETO, F. et al. Productive viability and profitability of carrot-cowpea intercropping using different amounts of Calotropis procera. Revista Caatinga, 32.1: 62-71, 2019.

CONAB - Companhia Nacional de Abastecimento. Brazilian Horticulture Market Modernization Program (PROHORT). Disponível em: <http:// dw.ceasa.gov.br/>. Acesso em: 10 dez. 2020.

FERREIRA, D. F. Sisvar: a computer statistical analysis system. Ciência e Agrotecnologia, 35: 1039-1042, 2011.

GÓES, S. B. et al. Productive performance of lettuce at different amounts and times of decomposition of dry scarlet starglory. Ciência Agronômica, 42: 1036, 2011.

GRANGEIRO, L. C. et al. Accumulation and exportation of nutrients in beet crop. Ciência e Agrotecnologia, 31: 267-273, 2007.

MORAES, E. C. et al. Effects of different roostertree (Calotropis procera) amounts and spatial arrangements on the performance of the beet-cowpea intercropping system. Australian Journal of Crop Science, 13: 486-493, 2019.

NASCIMENTO, A. F. D.; MATTOS, J. L. S. D. Benefits with green manures use. Revista Brasileira de Agroecologia, 2: 41-55, 2007.

NUNES, R. L. C. et al. Effect of green manuring with Merremia aegyptia on agro-economic efficiency of radish production. Revista Caatinga, 33.4: 964-973, 2020.

OLIVEIRA, K. J. B. et al. Agroeconomic production of the rocket fertilized with different amounts of Calotropis procera. Terceiro Incluído, 5: 373-384, 2015a.

OLIVEIRA, L. A. D. A. et al. Agronomic feasibility of polycultures of arugula/carrot/lettuce under amounts of roostertree and population densities. Revista Caatinga, 28: 116-126, 2015 b.

OLIVEIRA, M. K. T. et al. Agroeconomic performance of carrot fertilized with scarlet starglory (Merremia aegyptia). Horticultura Brasileira, 30: 433-439, 2012. 
SILVA, A. F. A. et al. Agronomic performance in radish fertilized with Calotropis procera (Ait.) R. Br.in two growing seasons. Ciência Agronômica, 48: 328-336, 2017.

SILVA, A. F. A. et al. Profitability of radish fertilized with 'flor-de-seda' in two cultivation seasons in the semiarid region of Pernambuco state, Brazil. Amazonian Journal of Agricultural and Environmental Sciences, 58: 198-207, 2015.

SILVA, M. L. D. et al. Production of sugar beet fertilized with scarlet starglory at different doses and times of incorporation to soil. Revista Brasileira de Engenharia Agrícola e Ambiental, 15: 801-809, 2011.

SOUZA, E. G. F. et al. Agronomic response of arugula to green fertilization with rooster tree during two culture times. African Journal of Agricultural Research, 11: 4931-4938, 2016.

SOUZA, E. G. F. et al. Economic evaluation of lettuce fertilized with biomass of Calotropis procera in two growing seasons. Revista Caatinga, 32.1: 2740, 2019.

SOUZA, E. G. F. et al. Production of lettuce under green manuring with Calotropis procera in two cultivation seasons. Revista Caatinga, 30: 391-400, 2017.

SOUZA, Ê. G. F. et al. Profitability of rocket fertilized with roostertree biomass as a function of cultivation season. Revista Caatinga, 28: 65-77, 2015.

TORRES, J. L. R. et al. Cover crops residue decomposition and nitrogen release in a Cerrado soil. Revista Brasileira de Ciência do Solo, 29: 609-618, 2005. 